\title{
IMPLEMENTATION OF PRINCIPAL PERSONALITY COMPETENCY AS A CHANGE AGENT ON SCHOOL ACHIEVEMENT IN REMOTE AREA ONE ROOF SCHOOL
}

\author{
Juharyanto \\ Department of Educational Management, State University of Malang, Indonesia \\ juharyanto.fip@um.ac.id
}

\begin{abstract}
This study aims to describe the implementation of the competence of the principal's personality as an agent of change in the school achievement. This research was conducted by using the qualitative approach of the phenomenological type with multi case design. Data collection techniques are conducted through observation, documentation and in-depth interviews. Data were analyzed by: (1) data reduction, (2) data presentation, and (3), conclusion drawing. The resulting findings are among others: (a) expertly communicates vision, mission, and program indicators; (b) able to internalize the values of spiritual integrity and leadership; (c) have a strong desire to develop his knowledge; (d) be opened to all inputs of ideas and aspirations; (e) capable of effective coordination with related parties; and (f) skillfully delegate his leadership duties. Other findings identified were the principal as a risk taker plays a major role for school change and all the elements involved with school/madrasah by applying awareness-based leadership patterns, expectations, and concerns.
\end{abstract}

Keywords: Principal personality competency, change agent, school achievement

\section{INTRODUCTION}

The 1945 Constitution states that "Every citizen is entitled to education and instruction". The statement expressly requires the education apparatus to provide fair and quality education and teaching services to all citizens as a whole, "without selective logging". Quality education services can only be implemented by schools as a quality organization. Organizational presence is a necessity [1], therefore every individual cannot isolate himself from the school organization [2].

Organization dynamically is a harmonious, systematic process of cooperation between people in a formal and hierarchical ties and acts in accordance with agreed terms to achieve the goals set out effectively and efficiently [3].

Not all school organizations recognize the importance of school as an organization. His attention is more focused on policy and curriculum issues and is preoccupied with achieving purely academic achievement targets [4]. As a result, the graduates cannot take part in their community [4]. YB Mangunwijaya said that the new Indonesian people is still called as "Lost Generation" [5]. Tri Murti stated that they are only "clever and intellectually sharp" and are no longer "forms a sense of wholeness, oneness and unity with the All Being and the Whole of Humanity" [6]. School success is only seen from dimensions that appear to be measurable and quantifiable, especially the acquisition of the $\mathrm{UN}$ and the physical condition of the school, by negating other dimensions, which are soft, including values, beliefs, cultures and behavioral norms called the human side of organization. It is more influential on the performance of individuals and organizations (schools), to be superior [7]. Education must be able to accommodate all domains, practicing religious values, through various competencies and life skill [8].

The previous study shows that there is a positive and convincing correlation between principal leadership behaviors and teacher performance, pupil achievement, community involvement, intellectual quality of schoolchildren, and overall school performance [9]. To clarify the statement, many studies have found and concluded that principals are key people who play an important role in school progress [8], [10]. Headmasters become the benchmarks of school success and failure. Even the future of school is in the hands of the principal. Thus, the principal is a key leader who inspires all the citizens of the school to make changes for the progress of the school to the top of the highest school achievement. Therefore, becoming a principal is not easy. The principal is an individual who is appointed because it has adequate competence and is more reliable than other teachers [11], [12]. One of the main competencies that must be owned, mastered and practiced by the principal is personality competence [13], [14].

Personality becomes the foundation of leadership, because personality is a set of dynamic and organized characteristics possessed by a leader that uniquely influences his cognition, motivation, and leadership behavior. The dynamics and uniqueness of personality is not merely as innate but also the result of learning from the consequences of individual interactions with the environment in the form of experience or learning outcomes. For the principal, the dynamics of personality must be in line with his role as leader. The personality changes should support the effectiveness of the leadership being carried out. Principals with strong personalities are required to be consistent in their thinking, attitude, speech, commitment / loyalty / dedication / high work ethic and firm in making decisions on every major task and function [13], [14]

In running the organization, the principal must have a high sense of curiosity about the policy, theory, new practice in connection with the implementation of his duties, and able to independently develop himself as an effort to fulfill his curiosity. The principal has a tendency to always transparently and proportionately inform others of the plans, processes, and 
effectiveness, advantages and disadvantages of the implementation of a task and to be open to suggestions and criticisms on the performance of their duties [15].

Every school as an organization is not a problem. The ability to control himself in the face of problems, must have. The emotional stability of principals in controlling the atmosphere is not conducive to capital for school personnel in creating effective schools. Effective schools require the principal to have an effective job interest and a strong leadership spirit. Responsibility for the programming changes that occur in schools is often left to someone, the principal [16]. Therefore, the principal, as a reformer agent [17], [18] should be a person of intelligence and vision and foresight in view of the increasingly global reality of society.

In relation to its role as a change agent at school, according to Neagley and Evans [19] principals are required to provide leadership in the sense of: (1) accepting responsibility for their own innovation; (2) creating an open climate that allows teachers to feel free to innovate; (3) trying to build the school's organizational health as best as possible; (4) allowing teachers to conduct trial and error without fear of punishment; (5) give praise and without censure that makes the teachers hostile to one another; And (6) provide essential facilities for the assessment and sustainability of sustainable innovations.

The principal as a change agent has a great responsibility to deal with the changing resistance within the organization of the school he leads, especially if his organization is already established [20], [21]. Resistance often occurs because it sees change from a different point of view. For the headmaster the change means opportunities, both for school and for himself. However, for some residents of the school, change is seen as chaos and disorder. Peter Scholtes holds that essentially employees (teachers) do not resist change, but refuse to change [22]. To overcome this, the principal must balance the personal compact of his worker, which includes three dimensions, namely formal, psychological and social [23].

Jerald Greenberg (2003) identifies five factors that prevent a person from changing: a) Economic Insecurity. Resistance that raises the potential for job loss or wage decline. B) Fear of the unknown, aroused by the fear of facing the consequences of a change whose form is unclear. C) Threats to social relationships. A change can undermine the undesirable social relations order. D) Habits. Changing habits is perceived as discomfort leading to resistance. E) Failure to recognize need for change. Resistance due to lack of understanding.

There are four barriers to organizational change, such as: a) Structural Inertia, Organizational power acts on the worker, encouraging them to realize their work in a particular way (eg training, reward system) that makes them resistant to change. B) inertia work group. Inertia to realize work in a special way not only comes from their own work, but also from other social groups that can influence the working group within the organization. C) threats to existing balance of. At this time, the unit now controls resources, possesses expertise, and holds strength, perhaps afraid of losing favorable positions that may be obtained from organizational change. D). Previously unsuccessful change effort [24].

School as a social system has the duty to perform roles, functions and expectations to achieve the goals of a system and to recognize different individuals in learners who have the personality and disposition needs. The task, implicitly directing schools as a social change, is also tasked with capturing existing values in society to be implemented into the school system [20], [25]. Even educational institutions / schools are "cultural institutions" that use cultural symbols, which function as "agents of renewal" that introduce the idea of rural development; As well as the center of community learning [20], [26]. The achievement of the implementation of cultural symbols into school contexts that are mixed into school policy, its estuary is the achievement of school achievement. Schools with high achievement are also called successful schools [27]. Achieving schools are schools that always make continuous improvement efforts (Walker \& Qian, 2015) that emphasize the increasing achievement of learners and the ability of schools to make a breakthrough school changes to a better known as the term school improvement.

Mackenzie [30] identifies three effective dimensions of education: leadership, effectiveness and efficiency as well as the underlying and supporting elements of each of these dimensions. Edmons [31] mentions five characteristics of an effective school: (1) leadership and attention of the principal to the quality of teaching, (2) a deep understanding of teaching, (3) a comfortable and orderly climate for the ongoing teaching And learning, (4) expectations that all students will at least master certain knowledge, and (5) student ratings based on the results of measurement of student learning outcomes.

One roof school (SATAP), is a unique school, with very specific characteristics, unlike other schools. SATAP is an education management system that combines two different levels of basic education (SDSMP) that are in one management. SATAP is an alternative education service for the outlying, rural, or outer regions and border areas. SATAP implements the same system of education with other regular schools, especially in conducting education and learning processes in accordance with the 8 national standards of education. The same demands as regular schools, but the managerial and institutional character, as well as the conditions in the periphery with different social, economic, and cultural complexes, make SATAP appear as an educational institution faced with its own complexity. The three SATAPs in this study represent these characteristics. Nevertheless, still struggling to stretch the process of becoming a national standard school.

\section{METHODS}

This research was conducted by using qualitative approach of phenomenological type with multi case design. Data collection techniques are 
conducted through: Observation, documentation and in-depth interviews. After validity checks, the data are analyzed by (1) data reduction, (2) Presentation of data and (3), Conclusion drawing. This research was conducted at three one roof schools in East Java. The designation of the site was made on the recommendation of LPKIPI (Institute for Policy Development and Innovation of Education Indonesia) East Java.

\section{RESULTS AND DISCUSSION}

Personality competence becomes the cornerstone of leadership, because personality is a set of dynamic and organized characteristics possessed by a leader and uniquely influences his cognition, motivation, and leadership behavior. The dynamics and uniqueness of personality besides as innate but also result of learning from result of individual interaction with environment in the form of experience or learning result. For the principal, the dynamics of personality must be in line with his role as leader. The personality changes should support the effectiveness of the leadership being carried out.

Effective principals are individuals who have personality integrity as leaders. The personality integrity shown by the SATAP principal is as in his statement.

"kami kan punya prinsip bahwa seperti yang dipegang teguh oleh sesepuh-sesepuh masyarakat sini, untuk memegang landasan bahwa nilai-nilai dan tradisi masyarakat harus tetap dipegang teguh, kecuali memang ada hal-hal baru yang dapat menjadikan sekolah lebih baik, ya.. perlu diambil juga. Jadi sesuatu yang baru kalau itu lebih baik dari yang lama itu yang selalu kita ambil". (SATAP1/KK/K/1/014)

Personality integrity is based more on normative values that are believed and valid in society by trying to do maximum ikhtiyar (effort) while still upholding the old values are still good.

Implementation of the integrity of the principal's personality manifested in various forms of activities, among others: istighotsah, duha prayer, hospitality to the nearest boarding school, happy to seek advice to the ulama, enforcement of values of obedience to leaders and community leaders, extra facilitation leading to planting Love of religion and nation through Sholawat, and others. Everything is done to keep up the values of aswaja which historically continue to be integrated into the pulse of education and teaching process at SATAP Bondowoso. The ultimate goal is the achievements of the world and the hereafter.

In connection therewith, the Principal of SATAP explains:

"target kita menjadikan sekolah kita berstandar. Sekolah ini kan unik. Dua sekolah beda tingkatan dikelola oleh satu pengelola. Karakter masing-masing sekolah juga beda kan? Standar seperti sekolah lain yang reguler, itu yang kita tuju. Jadi dengan indikator yang jelas. Standar SD itu apa, SMP itu apa. Tentunya punya prestasi akademik itu kan... nilai UN nya bagus, prestasi akademiknya bagus. Itu kan standar... standar. Sarananya bagus... Tetapi standar karakternya itu perlu kita tanamkan juga. Karena sering kali ketika sekolah sudah mengejar prestasi, karakter ndak. Ini terkait dengan misi dakwah juga. Saat ini anak-anak menyukai lagu-lagu

\begin{abstract}
juga itu ya... lagu-lagu yang sudah kebarat-baratan. Makanya kami kemudian melakukan kegiatan mengembangkan potensi itu karena biasanya anak-anak kan suka meniru". (SATAP2/KK/K/1/021)
\end{abstract}

In line with the statement of the principal, Mr. Agus as a senior teacher at SATAP Tlogosari justify it. According to him the hope of such activities could have an impact on the increasing spirit of the struggle in this SATAP while confident that every struggle must give the best result in the inner birth. More specifically he said:

"Kebanyakan dari teman-teman itu berangkatnya adalah dari sisi ibadah. Bayangkan saja, sekolah kami ada dua lembaga dalam satu pengelolaan. Hanya 3 orang guru dari 15 guru yang PNS. Lainnya non-PNS dengan honor yang tidak tentu. Jadi berangkatnya dari sisi itu. Sehingga beban yang sangat berat itu dan padat pekerjaan itu dianggap sesuatu yang menghasilkan luar biasa harapannya. Nah yang ditanamkan oleh lembaga bahwa SDM yang ada berjuang di sini, ya namanya perjuangan ya pasti berat. Soal hasil itu apa katanya Allah. Itu yang jelas di situ". (SATAP3/KK/G1/1/083)

Integrity to the values of discipline is not only strengthened into the form of coordinative or instructive appreciation. The awareness that exemplary factors uphold the integrity of the value of discipline and other character values becomes an important factor for the success of enforcing it. Therefore, the model of teacher modeled by the headmaster and all SATAP employees is the hallmark of imperatives that are continuously developed into the habituation program.

These established and developed foundations have not only become the main attraction for society, but also have placed SATAP into a basic educational institution to be a patron for the birth of a continuing elementary school in order to achieve national standards, as well as other regular schools.

Based on field data, these three one-roof schools are supported by principals who have strong personality integrity as leaders. The integrity of the personality becomes the headmaster's impulse to do many things, among others, to strive for continuous self-development, to be open to all forms of information to positive change, to strive for self-control in the face of every issue, and the principal has a leadership talent effective. The overall values of integrity that exist in the headmaster are directed to fight for the school to be a school achievement [32].

There are six principal things that principals do in manifesting personality integrity in three schools into a national standard school, among others: 1) a proactive attitude in communicating vision, vision, mission, and program indicators to gain strong support and trust for institutional development programs ; 2) able to internalize the values of spiritual integrity and leadership through a variety of formal and informal activities; 3) has a strong desire in developing knowledge by involving themselves in the activities of professional organizations; 4) be open to all inputs of ideas and aspirations from all elements of the school; 5) able to coordinate effectively with related parties in order to find the right solution; 6) able to delegate their leadership tasks in accordance with the right man on 
the right place principle, both with the aim of disseminating leadership skills with mobile leadership model, empathetic leadership, or even making the institution of school / madrasah as a leadership laboratory.

Personality competence is part of the psychological character that influences the leader's ability to take decisions in responding to environmental changes effectively [33]. Such responses can be vision and mission internalized from the context that occurs and embodied into decisions and policies that support school organizational effectiveness. Personality is a set of dynamic and organized characteristics possessed by a leader who uniquely influences the person's cognition, motivation, leadership behavior. The personal integrity of the principal as the leader of the school organization is not merely capable of transforming the values of locality-based leadership to the entire organizational element, but will further ensure the robustness of the school organization's building itself.

Psychologically, the leadership behavior of a principal who has a strong personality integrity begins with a conscious attitude to what happens to him, his organization, the individuals surrounding him, and the context of his self-consciousness. Such awareness will give rise to a high expectation on an organizational scale, that is, building strength through the ideal and rational ideal of organizational stimuli where the principal is the key person in the organization. These expectations are not only excavated on the basis of the self-potential of the school principal, but are reconstructed from the potential of organizational locality, the individual within the organization, and the organizational context that is collaborated in such a way as to values the organization of local and global character. Effective leaders are leaders who are able to exert powerful influence gained through the leader's caring attitude (sympathy and empathy) towards all individual and social phenomena of the organization. The integration of mindfulness, expectation and the headmaster's com- passion, which is reconstructed effectively into resource potentials will be an increasingly powerful force capable of producing truly outstanding schools, Outward and bathiniyah. The leader is called a resonant leader who adopts a pattern of resonant leadership, an insightful maneuver that thrills the hearts of followers to give more to the organization [34]. "Effective teams and powerful, positive organizational cultures do not happen by accident, they are emotional intelligence to motivate and nurture their employees" [34].

The integrity of the principal who resonates into the organization is reflected in: 1) the integrity of vision with local values; 2) internalizing local values into school programs; 3) promoting local-based school / madrasah programs (local wisdom based); And 4) to behave aspiratively, humanist, emphatic, and empathetic can also play a role in strengthening the level of acceptability and community support for schools to continue to achieve.

In the three Schools one roof is found a number of similarities in terms of cultural awareness by the head of a one-roof school that became the basis for policy flexibility is applied. This awareness ultimately becomes the principal ingredient for the principal in communicating, reorganizing, coaching, curriculum development, creating a conducive working climate, performance appraisal, and other creative innovations. Each principal is also aware that every change must be made, therefore the principal acts as a catalyst, solution giver, resource linker, and confidence builder. And the risk of any change effort is realized to be dealt with prudently (risk taker) so that the change takes place and is beneficial for the future of school achievement.

\section{CONCLUSIONS}

The quality of acceptability and support to the school / madrasah development effort for achievement by the community (internal / external) embodies in: 1) the integrity of vision with local values; 2) alignment of school / madrasah program to local potential (local wisdom based); And 3) leadership-based "resonant leadership" leadership integrity.

In addition, as agent of change, the principal has the following characteristics: cultural awareness, skill in communication, reorganization, coaching, curriculum development, creation of conducive working climate, performance appraisal, and other creative innovations. In applying its leadership, the principal acts as a catalyst, solution giver, resource linker, and confidence builder and acts as a risk taker.

\section{REFERENCES}

[1] Wahyudi and H. Retnowati, "Pengaruh Kepemimpinan Transformasional Kepala Sekolah, Pelaksanaan Mbs, Dan Pelaksanaan Tu Terhadap Kualitas Pendidikan Sd/Mi Depok Sleman," J. Akuntabilitas Manaj. Pendidik., vol. 2, pp. 250-264, 2014.

[2] E. O. F. State, B. Energies, B. Modulus, and G. R. Uneisen, "1. Introduction," in Spiritual Leadership in the Entrepreneurial Business, vol. v, no. 1997, 2003, pp. 23-40.

[3] S. P. Robbins, Organizational behavior: concepts, controversies, and applications. Englewood Clift, New Jersey: Prentice Hall, 1989.

[4] Darmaningtyas, Pendidikan yang memiskinkan. Yogyakarta: Galang Press, 2015.

[5] S. Tono, Kita Lebih Bodoh dari Generasi SoekarnoHatta. Jakarta: Visi Gagas Komunika, 2000.

[6] M. V. Mohr, The Call of the Hibiscus: Indonesia's Message to The World. Jakarta: PT. Inti Indayu Press, 1984.

[7] D. G. Sampson, D. Ifenthaler, J. M. Spector, and P. Isaias, Digital systems for open access to formal and informal learning. 2014

[8] Z. Mbokazi, "Dimensions of successful leadership in Soweto township secondary schools," vol. 43 , no. 3 , pp. 468-482, 2015.

[9] C.-H. Lum, Contextualized Practices in Arts Education: An International Dialogue on Singapore, no. Book, Whole. 2013.

[10] R. Hill and I. James, "Reviewing the self-assessment of governing body performance in colleges and schools in England," vol. 44, no. 5, pp. 745-756, 2016.

[11] M. Yasin and L. M. Tahir, "Principal Competencies and the Achievement of National Education Standard in 
Indonesia," vol. 2, no. 8, pp. 31-36, 2013.

[12] B. Zizek, D. Garz, and E. Nowk, Moral Development and Citizenship Education. 2015.

[13] E. Karada and E. Studies, Leadership and Organizational Outcomes. 2015.

[14] C. W. K. W. Seong Ng Foo David, NguyenGong Thanh, Benjamin Koon Siak Wong Benjamin Koon Siak, "A review of Singapore principals" leadership qualities, styles, and roles," J. Educ. Adm., vol. 53, no. 4, pp. 512-533, 2015.

[15] Kementerian Pendidikan Nasional, Peraturan Menteri Pendidikan Nasional RI Nomor 13 Tahun 2007 Tanggal 17 April 2007 Tentang Standar Kompetensi Kepala Sekolah/Madrasah, no. April. Indonesia, 2007, pp. 1-6.

[16] J. T. Hines, "Work in Inclusive High School Classrooms :," vol. 2008, pp. 277-282, 2015.

[17] G. Bezzina, "The Maltese Primary School Principalship: Perception, Roles and Responsibilities," Brunei University School of Education, 1995.

[18] Finney Cherian \& Yvette Daniel, "Principal Leadership in New Teacher Induction: Becoming Agents of Change," Int. J. Educ. Policy Leadersh., vol. 3, no. 2, pp. $1-11,2008$.

[19] I. Bafadal, "Proses Perubahan di Sekolah: Studi Multisitus pada Tiga Sekolah Dasar yang Baik di Sumekar," Institut Kaguruan dan Ilmu Pendidikan, Malang, 1995.

[20] G. Tchibozo, Cultural and Social Diversity and the Transition from Education to Work, vol. 17. 2013.

[21] G. Lakomski and G. Lakomski, "Organizational change , leadership and learning : culture as cognitive process," 2006.

[22] M. Stettner, The new manager's handbook: 24 lessons for mastering your new role. New York: McGrawwHills Companies, 2003.

[23] P. Strebel, Why Do Employees Resist Change, vol. 74. 1996.

[24] R. A. B. Jerald Greenberg, Behavior in organizations : understanding and managing the human side of work, 8th ed. New Jersey: Prentice Hall Inc, 2003.

[25] D. Van Maele and M. Van Houtte, "Trust in school: a pathway to inhibit teacher burnout?," J. Acad. Adm. vol. 53, no. 1, pp. 93-115, 2015.

[26] T. Male and I. Palaiologou, "Pedagogical leadership in the 21st century: Evidence from the field," Educ. Manag. Adm. Leadersh., vol. 43, no. 2, pp. 214-231, 2013.

[27] R. Reynolds et al., Contesting and constructing international perspectives in global education. 2015.

[28] P. Hallinger, A. Walker, and G. T. Trung, "Making sense of images of fact and fiction," J. Educ. Adm., vol. 53, no. 4, pp. 445-466, 2015.

[29] A. Walker and H. Qian, "Review of research on school principal leadership in mainland China, 1998-2013 Continuity and change," J. Educ. Adm., vol. 53, no. 4, SI, pp. 467-491, 2015.

[30] J. Warwas, "Principals' leadership behaviour: valuesbased, contingent or both?," J. Educ. Adm., vol. 53, no. 3, p. 310, 2015.

[31] S. Marsh, M. Waniganayake, and I. W. Gibson, "Scaffolding leadership for learning in school education," Educ. Manag. Adm. Leadersh., vol. 42, no. 4, pp. 474-490, 2014.

[32] Juharyanto, "Kepemimpinan unggul Kepala Sekolah Dasar Daerah Terpencil (Studi Multisitus pada Sekolah Dasar di Kabupaten Bondowoso)," J. Sekol. Dasar, vol. 1, no. Tahun 26, 2017.

[33] and C. A. R. Enedina García-Vázquez, Tony D. Crespi, Ed., Handbook of Education, Training, and
Supervision of School Psychologists in School and Community, Volume I. New York: Taylor and Francis Group, LLC, 2010.

[34] R. Boyatzis and A. McKee, Resonan leadership, Memperbaharui Diri Anda dan Berhubungan dengan Orang Lain melalui Kesadaran, Harapan dan Kepedulian. Jakarta: PT. Gelora Aksara Pratama, 2010. 